\title{
Effect of High Temperature and Exposure Time on Erysiphe necator Growth and Reproduction: Revisions to the UC Davis Powdery Mildew Risk Index
}

Francesca Peduto, Peggy Backup, Eric K. Hand, Christopher N. Janousek, and Walter D. Gubler, Department of Plant Pathology, University of California-Davis, Davis 95616

\begin{abstract}
Peduto, F., Backup, P., Hand, E. K., Janousek, C. N., and Gubler, W. D. 2013. Effect of high temperature and exposure time on Erysiphe necator growth and reproduction: Revisions to the UC Davis Powdery Mildew Risk Index. Plant Dis. 97:1438-1447.

Epidemics of powdery mildew, the most important disease of grapevines in California, are driven by moderate temperatures $\left(21\right.$ to $\left.30^{\circ} \mathrm{C}\right)$. High temperatures can delay or stop the growth and sporulation of Erysiphe necator. Using controlled conditions, we investigated the response of the pathogen's colony growth, conidiospore production, and germination to eight temperatures $\left(30\right.$ to $\left.44^{\circ} \mathrm{C}\right)$ at 12 exposure times $(0.25$ to $24 \mathrm{~h})$. The pathogen survived, grew, and reproduced at higher temperatures than previously reported; exposure time was as important as temperature in defining lethal and sublethal effects. Lethal

increasing temperature. Based on this new information on the pathogen's biology, we tested revisions to the high-temperature threshold of the UC Davis Powdery Mildew Risk Index in field settings. No differences in the total number of fungicide applications resulted from the use of either the original or the revised models. However, use of the $38^{\circ} \mathrm{C}$ for $2 \mathrm{~h}$ threshold consistently showed equal (leaves) or better (fruit) disease control compared with the original model, as well as equal disease control compared with a calendar schedule, but with five fewer applications over the 2 years of the study.
\end{abstract} effects started at 36 to $38^{\circ} \mathrm{C}$. Lethal exposure times decreased with
Grapevine powdery mildew caused by Erysiphe necator Schwein. is the most common and economically important disease of grapevines worldwide (25) and is the target of the majority of fungicides used in vineyards $(12,14)$. Early infections can be cryptic but, once established, powdery mildew epidemics are characterized by exponential asexual reproduction via conidiospores and, therefore, are more easily prevented than eradicated. Hence, there is a tendency for prophylactic treatments against this obligate parasite. Although temperature is not the only environmental factor limiting growth and reproduction of this biotroph, it is one of the most important variables regulating the dynamics of vineyard epidemics. Both high-temperature exposure and acute cold temperatures reduce E. necator growth and infection efficiency $(23,35)$.

The maximum temperature exposures at which E. necator conidia germinate has been variously reported as $33.5^{\circ} \mathrm{C}$ for $24 \mathrm{~h}$ and $40.5^{\circ} \mathrm{C}$ for $4 \mathrm{~h}(10), 34$ or $36^{\circ} \mathrm{C}$ for an unspecified exposure time (35), and $40^{\circ} \mathrm{C}$ for $3 \mathrm{~h}$ (36). In the presence of UV light, existing colonies are damaged by exposure to $35^{\circ} \mathrm{C}$ for $0.25 \mathrm{~h}$ (16). All stages of the life cycle are destroyed by extended exposure to $33^{\circ} \mathrm{C}$ or $12 \mathrm{~h}$ of exposure above $35^{\circ} \mathrm{C}(16)$. Mature colonies are killed by exposure to $35.5^{\circ} \mathrm{C}$ for more than 2.5 days or to $40.5^{\circ} \mathrm{C}$ for 4 to $6 \mathrm{~h}$ (10). Various studies show that optimum temperatures for $E$. necator range from $25^{\circ} \mathrm{C}$ (11) to $26^{\circ} \mathrm{C}$ (35) in the laboratory, and from 21 to $30^{\circ} \mathrm{C}$ in the field (16).

Corresponding author: Walter D. Gubler, E-mail: wdgubler@ucdavis.edu

Current address of F. Peduto: Department of Plant Pathology, The Ohio State University, Columbus 43210.

Current address of C. N. Janousek: Western Ecology Division, U.S. Environmental Protection Agency, Newport, OR 97365.

* The $\boldsymbol{e}$-Xtra logo stands for "electronic extra" and indicates that a supplementary table is available online.

Accepted for publication 17 April 2013.

http://dx.doi.org/10.1094/PDIS-01-13-0039-RE

(C) 2013 The American Phytopathological Society
The primary goals of powdery mildew models are to improve disease management $(18,31)$, avoid unnecessary fungicide applications (9), and reduce development of resistance to fungicides (36). Most but not all (9) models developed to predict E. necator disease outbreaks for Mediterranean climates focus on temperature as the critical factor, and either ignore moisture and humidity or confine its role to initiation events $(6,16,28)$. Perhaps the most insightful early model evaluated the influence of temperature, rain, and timing of initial infection on subsequent epidemics of E. necator (29); the resulting advisories were based on temperature and vine phenology. More recently developed temporal and spatiotemporal logistic models (5) confirmed the importance of early-season inoculum to epidemic development and showed a positive correlation between $E$. necator pathogenicity and high host vigor. A recent model from Canada (8) uses degree-days and grape phenological stage to guide the timing of early-season fungicide applications. In contrast, a new model from Italy (4) relies on host phenology and weather-based predictions of ascospore release to time early-season fungicide applications. Other investigators reported that earlyseason acute low-temperature events transiently reduce E. necator growth and fecundity (23). This convergence of several new approaches to powdery mildew forecasting and greater insight into the pathogen's biology indicates strong interest in strengthening existing models and suggests that different disease management models may be appropriate for different climates.

A survey conducted in California (20) indicated that over half of winegrape growers in the state use the UC Davis Powdery Mildew Risk Index (PMI; 16) as a tool to time fungicide applications or to dictate what fungicide is applied. Its use has been credited for improved control of powdery mildew and decreased use of fungicides $(16,20,32)$. The PMI was derived from both laboratory and field trials and uses daily temperature averages to predict disease pressure after a rainfall or temperature event begins the disease cycle via ascospore release. Fine-tuning the PMI for high temperatures could allow better control of powdery mildew, which may improve crop yield, quality, and profitability. Improving model precision may also allow a further reduction in fungicide applications per season by making the model less conservative. With global climate change, the need to understand the effects of high and low temperatures on pathogens and hosts may increase in importance $(1,15)$. 
We designed the present study as a systematic time course investigation to improve our understanding of the effects of high temperature on grape powdery mildew and how those data could inform disease management practices in vineyards. Our objectives were to (i) determine what temperature-duration combinations were lethal to E. necator, (ii) identify sublethal conditions that delayed E. necator growth, (iii) assess whether sublethal and lethal effects impacted different cycle stages or pathogen isolates differently and (iv) integrate the aforementioned information on the pathogen's biology into the UC PMI to determine whether a revision to the high-temperature threshold should be proposed.

\section{Materials and Methods}

Culture growth and maintenance. As an obligate parasite, $E$. necator cannot be grown on defined media but it responds well to a variety of leaf and leaf disk systems with and without agar $(30,36)$. Grapevines (Vitis vinifera) of the highly susceptible 'Carignane' were raised in a glasshouse to provide a year-round source of young, disease-free leaves for controlled-environment experiments and to maintain E. necator isolates. Continual growth was obtained through frequent pruning, supplemental heat and light during the winter, and daily watering with dilute Hoagland's nutrient solution (17). Early-morning vaporized sulfur applications prevented infection by the pathogen in the greenhouse. Unblemished, disease-free young leaves (leaves 3 to 5 ) were harvested for use in leaf cocultures. Leaves were rinsed in sterile distilled water (SDW), immersed in $0.6 \%$ sodium hypochlorite for $1 \mathrm{~min}$, rinsed in SDW again, and blotted dry. A thin layer of dilute water agar (12 g/liter) plus Avid 0.15 (avermectin B1 Solution, Merck; $1 \mu \mathrm{l}$ formulation/liter) for mite control was poured into petri plates in a sterile hood. One leaf per dish was placed upside down on top of cooling agar just before it solidified. Leaves bonded with the agar, which provided moisture to prevent desiccation at high-temperature treatments $(24,35)$ and provided flat, stable surfaces on which to measure colony growth. Leaves were kept in the laboratory at room temperature $\left(22.5^{\circ} \mathrm{C}\right)$, with ambient light, and remained green for up to 1 month. Excess moisture was controlled by drying plates every other day with opened lids in a sterile hood until condensate disappeared (typically $20 \mathrm{~min}$ ).

Four isolates of E. necator were obtained in 2007 from California vineyards representing four production regions: Central Valley, Delta, Coastal, and Inland. Because the experimental design required nearly $100 \%$ success in leaf infection, and because single conidia infection rates can be low $(22,24)$, a chain of conidia was transferred via an eyelash affixed to a toothpick to leaves at premarked sites on the abaxial surface (19). Spore production in colonies held at room temperature $\left(22^{\circ} \mathrm{C}\right)$ did not change appreciably for over 2 years, suggesting no change in pathogen virulence (data not shown; $n=90$; slope was nearly horizontal). Leaves were incubated in two Fisher Scientific Isotemp forced-air incubators. Thermocouples were placed outside the incubators and in the following locations inside incubators: in contact with leaf surfaces inside petri plates, on top of the petri plate lid, and on incubator shelves. METOS (Pessl Instruments, GmbH) weather station thin-wire thermocouple sensors were used to compare indicated incubator air temperatures with leaf surface temperatures and to evaluate temperature changes at the leaf surface after opening incubator doors. Sensor data showed that the discrepancy between leaf surface temperature and the indicated air temperature inside incubators was $<1^{\circ} \mathrm{C}$ between 30 and $44^{\circ} \mathrm{C}$. After bringing incubators to the desired temperature, opening the door for $30 \mathrm{~s}$ decreased average leaf surface temperature by $<1^{\circ} \mathrm{C}$, and temperature rapidly returned to the set value after closing the doors.

Life stage assays. The effects of eight temperatures $(30,32,35$, $36,38,40,42$, and $\left.44^{\circ} \mathrm{C}\right)$ at each of 12 exposure times $(0.25,0.5$, $1,1.5,2,4,6,8,12,18,20$, and $24 \mathrm{~h}$ ) were measured for three life stages of the fungus (colony growth, spore production, and spore germination). Each leaf represented one replicate, even if multiple colonies were measured per leaf. Depending on assay and treatment, replicate leaf numbers varied from 3 to 29, with more replicates used near response thresholds. All leaves were maintained at $22.5^{\circ} \mathrm{C}$ prior to and after heat treatment.

Leaves for assessing the effects of temperature on colony growth were exposed to each heat treatment once, on the third day following inoculation. Our choice to expose 3-day-old colonies to the different heat treatments derived from preliminary tests in which we found that 3 days was long enough for colonies to establish and short enough to allow leaves to survive the experiment (data not shown). Using a dissecting microscope, perpendicular colony diameters, which are highly correlated with colony area (21), were marked on the leaf surface at 2-day intervals. Colony size was measured from day 2 through day 10 following heat treatments. To test for sublethal effects, the incubation period (time from inoculation to first appearance of mycelia) for each colony that received heat treatment was compared with incubation period for room temperature controls $\left(22.5^{\circ} \mathrm{C} ; n=125\right)$. Delay in colony growth following heat treatments as well as survival rates of the colonies were calculated for every leaf and isolate and averaged for each temperature-duration combination.

After final colony size was measured on day 10, the effects of temperature on spore production were evaluated on the same leaves 15 days after inoculation. Leaf disks from existing colonies were excised with an 11-mm cork borer, placed in individual microcentrifuge tubes with $1 \mathrm{ml}$ of SDW and $1 \mu \mathrm{l}$ of Tween 20 (27), and vortexed for $20 \mathrm{~s}$. Leaf discs were removed, tubes were microcentrifuged for $2 \mathrm{~min}$ at high speed, and conidia were counted using a hemocytometer immediately after vortexing for $5 \mathrm{~s}$. Spore density was derived by dividing counts by colony area, which was calculated for colony diameters less than $11 \mathrm{~mm}$.

The effect of temperature on spore germination was assessed using conidia from heavily sporulating 15 day-old colonies held at room temperature $\left(22.5^{\circ} \mathrm{C}\right)$. Heat was applied once to the entire colony and conidia were then transferred onto glass slides by rub inoculation, placed in moist covered plastic containers at room temperature, and evaluated for germination $24 \mathrm{~h}$ later using light microscopy at $\times 100$ magnification. Conidia with visible appressoria or germ tubes greater than twice the conidial length were scored as germinated. At least 100 conidia per colony were scored to determine percent germination.

Field study. Revisions to the high-temperature threshold of the PMI were tested over two consecutive seasons (2011 to 2012) in different locations in northern (Solano and Sacramento Counties) and central (Fresno County) California. At each location, trials were established using a randomized complete bock design (six blocks) with three grapevines per block. Each trial had an in-vineyard weather station (iMETOS ag, Pessl Instruments, GmbH); hourly weather data were downloaded daily and the original PMI was calculated as described by Gubler et al. (16). Compared with the original threshold of the PMI $\left(35^{\circ} \mathrm{C}\right.$ for $\left.0.25 \mathrm{~h}\right)$, revisions were as follows: $34^{\circ} \mathrm{C}$ for $4 \mathrm{~h}, 36^{\circ} \mathrm{C}$ for $4 \mathrm{~h}$, and $38^{\circ} \mathrm{C}$ for $2 \mathrm{~h}$ (Table 1 ). As part of these revisions, information on the delay of fungal growth after a heat event was included in the index calculation.

Table 1. High-temperature thresholds of the original Powdery Mildew Risk Index (PMI), proposed revisions, and rules to calculate the index gains and losses

\begin{tabular}{|c|c|c|c|c|c|c|}
\hline PMI & $\begin{array}{l}\text { Points to add every day } \\
\text { with }>6 \mathrm{~h} \text { at } 21-30^{\circ} \mathrm{C}\end{array}$ & $\begin{array}{c}\text { High-temperature } \\
\text { threshold }\left({ }^{\circ} \mathbf{C}\right)\end{array}$ & $\begin{array}{c}\text { Time at } \\
\text { threshold (h) }\end{array}$ & $\begin{array}{l}\text { Points to subtract on day } \\
\text { threshold is reached }\end{array}$ & $\begin{array}{l}\text { Days to delay } \\
\text { index increase }\end{array}$ & $\begin{array}{l}\text { Points to subtract } \\
\text { each delay day }\end{array}$ \\
\hline Original & 20 & 35 & 0.25 & -10 & 0 & 0 \\
\hline $34^{\circ} \mathrm{C}$ for $4 \mathrm{~h}$ & 20 & 34 & 4 & -20 & 2 & -5 \\
\hline $36^{\circ} \mathrm{C}$ for $4 \mathrm{~h}$ & 20 & 36 & 4 & -20 & 4 & -5 \\
\hline $38^{\circ} \mathrm{C}$ for $2 \mathrm{~h}$ & 20 & 38 & 2 & -20 & 6 & -5 \\
\hline
\end{tabular}


After reaching the respective high-temperature thresholds, any gain the index would accrue the following day was delayed by two $\left(34^{\circ} \mathrm{C}\right.$ for $\left.4 \mathrm{~h}\right)$, four $\left(36^{\circ} \mathrm{C}\right.$ for $\left.4 \mathrm{~h}\right)$, or six $\left(38^{\circ} \mathrm{C}\right.$ fir $\left.2 \mathrm{~h}\right)$ days, and five extra points were subtracted from the index on each delay day (Table 1). Three different fungicides were applied in rotation: Quintec (quinoxyfen; Dow AgroSciences LLC), Luna Experience (fluopyram + tebuconazole; Bayer CropScience LP), and Flint (trifloxystrobin; Bayer CropScience LP) in 2011; and Quintec, Adament (tebuconazole + trifloxystrobin; Bayer CropScience LP), and Flint in 2012. Fungicides were applied at rates indicated on the labels and spraying intervals ranged from 14 days (PMI values 0 to 40 ) to 21 days (PMI values 50 to 100). For comparative purposes, treatments at each trial also included a calendar schedule (every 14 days starting at $25-\mathrm{cm}$ shoot length), as well as unsprayed controls.

In order to measure in situ disease progress (incidence and severity), trials were visited weekly starting the first week of May and continuing until grape berries reached approximately $10^{\circ} \mathrm{Brix}$ sugar content (31 July 2011, 26 July 2011, and 19 July 2012 in the Sacramento, Solano, and Fresno County trials, respectively). Every week, 18 fully expanded basal leaves were removed randomly from within the lower canopy of each experimental unit and both sides of each leaf were examined visually for presence of mildew colonies. When present, 18 grape clusters per unit were also inspected by examining all surfaces but not removed from the vines. Disease incidence was expressed as presence or absence of visible colonies on the plant tissues, whereas disease severity was expressed as an estimated percentage of total leaf or cluster area covered by mildew.

Statistical analyses. Life stage assays. Data were analyzed with SAS (v. 9.1; SAS Institute, Inc.) except as noted below. More than 2,200 leaves were heat treated in a series of experiments over 2 years (each experiment consisting of two randomly selected temperatures), with all treatment combinations (isolate, temperature, and duration of treatment) interspersed haphazardly over time. To examine the relative contribution of temperature, exposure time and isolate on colony growth, spore production, and spore germination, data were analyzed by type III three-factor analysis of variance (ANOVA) using PROC Mixed. To examine the relative contribution of exposure time and colony age on changes in colony size and growth rate from day 2 through day 10, data were analyzed with two-factor repeated-measures ANOVA. Delays in colony growth with different exposure durations were examined for each temperature ( 32 to $44^{\circ} \mathrm{C}$ ) with Kendall's rank correlation using $\mathrm{R}$ 2.14.1 ( $\mathrm{R}$ Development Core Team). No test was performed at $30^{\circ} \mathrm{C}$ because no replicates were delayed regardless of exposure time. Significance was set at $\alpha=0.05$ for all analyses.

Tolerance thresholds for the three major life stages of the pathogen to increasing exposure periods at high temperatures were examined with quantile regression (R, package "quantreg"). Regression at the upper distribution of the response variable, rather than estimating mean response as with standard ordinary least squares (OLS) regression, enabled estimation of the effects of exposure duration as a limiting biological factor (3). In our case, this allowed us to conservatively estimate the exposure times that were lethal for the majority of replicates tested (we used the $90 \%$ quantile to approximate the maximum pathogen response, because the $100 \%$ quantile cannot be computed and quantiles approaching $100 \%$ require increasingly large sample sizes). The relationship between maximum colony size, spore production, and spore germination and exposure duration were examined in a series of regressions spanning 30 to $44^{\circ} \mathrm{C}$ for each life stage. From the modeled quantile regression coefficients, the $\mathrm{x}$-intercept was calculated in order to estimate the length of time each life stage could tolerate a specific temperature before total loss of viability (zero colony growth, zero spore production, or 0\% spore germination). To avoid underestimating slopes (and, thus, overestimating exposure tolerance), data sets were truncated once an exposure duration was reached where the pathogen consistently showed no viability (i.e., if all replicates tested at 8 to $24 \mathrm{~h}$ of duration had $0 \%$ spore germination, they were removed from the analysis).

Field study. Statistical analyses were performed in JMP (v. 7; SAS Institute, Inc.). The effect of fungicide applications timed by the original PMI versus model revisions and a fixed-schedule spray protocol on disease incidence and severity was analyzed using mixed models, where treatment and week were considered fixed factors, and vineyard location, block, and leaf or cluster nested within block were treated as random factors. Means comparison was performed via Tukey's honestly significant difference tests using least squared means $(\alpha=0.05)$.

Table 2. Effects of temperature $\left({ }^{\circ} \mathrm{C}\right)$ and exposure time (h) on spore germination, colony size on day 10, and spore production of Erysiphe necator ${ }^{\mathrm{a}}$

\begin{tabular}{|c|c|c|c|c|}
\hline Life stage assay, factor & df & SS & $\boldsymbol{F}$ & $\boldsymbol{P}$ \\
\hline \multicolumn{5}{|l|}{ Spore germination (\%) } \\
\hline $\mathrm{H}$ & 11 & 100,246 & 46.18 & $<0.0001$ \\
\hline $\mathrm{T}$ & 7 & 155,661 & 119.84 & $<0.0001$ \\
\hline I & 3 & 589 & 0.70 & 0.37 \\
\hline $\mathrm{H} \times \mathrm{T}$ & 77 & 49,760 & 3.48 & $<0.0001$ \\
\hline $\mathrm{H} \times \mathrm{I}$ & 33 & 3,431 & 0.52 & 0.98 \\
\hline $\mathrm{T} \times \mathrm{I}$ & 21 & 6,108 & 1.57 & 0.06 \\
\hline $\mathrm{H} \times \mathrm{T} \times \mathrm{I}$ & 230 & 42,799 & 1.00 & 0.49 \\
\hline Error & 288 & 53,439 & $\ldots$ & $\ldots$ \\
\hline \multicolumn{5}{|l|}{ Colony size (mm) } \\
\hline $\mathrm{H}$ & 11 & 3,647 & 81.82 & $<0.0001$ \\
\hline $\mathrm{T}$ & 7 & 5,217 & 183.90 & $<0.0001$ \\
\hline I & 3 & 17 & 1.42 & 0.24 \\
\hline $\mathrm{H} \times \mathrm{T}$ & 77 & 2,901 & 9.30 & $<0.0001$ \\
\hline $\mathrm{H} \times \mathrm{I}$ & 33 & 94 & 0.70 & 0.89 \\
\hline $\mathrm{T} \times \mathrm{I}$ & 21 & 94 & 1.11 & 0.33 \\
\hline $\mathrm{H} \times \mathrm{T} \times \mathrm{I}$ & 221 & 615 & 0.69 & 0.99 \\
\hline \multirow{2}{*}{\multicolumn{5}{|c|}{ Spore production (conidia/ $/ \mathrm{mm}^{2}$ ) }} \\
\hline & & & & \\
\hline $\mathrm{H}$ & 11 & 583,372 & 37.96 & $<0.0001$ \\
\hline $\mathrm{T}$ & 7 & 498,633 & 50.99 & $<0.0001$ \\
\hline I & 3 & 7,805 & 1.86 & 0.13 \\
\hline $\mathrm{H} \times \mathrm{T}$ & 77 & 370,918 & 3.45 & $<0.0001$ \\
\hline $\mathrm{H} \times \mathrm{I}$ & 33 & 35,737 & 0.78 & 0.81 \\
\hline $\mathrm{T} \times \mathrm{I}$ & 21 & 26,724 & 0.91 & 0.58 \\
\hline $\mathrm{H} \times \mathrm{T} \times \mathrm{I}$ & 231 & 237,076 & 0.73 & 0.99 \\
\hline Error & 498 & 695,714 & $\ldots$ & $\ldots$ \\
\hline
\end{tabular}

a Abbreviations: $\mathrm{df}=$ degrees of freedom, $\mathrm{SS}=$ sum of squares, $\mathrm{H}=$ hour, $\mathrm{T}=$ temperature, and $\mathrm{I}=$ isolate. 


\section{Results}

Life stage assays. Temperature and duration of treatment significantly impacted pathogen growth, spore production, and spore germination (Table 2). Temperature and exposure duration also significantly interacted to affect all life stages. Isolate source was not significant individually or in interaction with other factors (Table 2).

Colony size and growth. At each temperature evaluated, exposure time had significant effects on colony size (Table 2; Fig. 1), which declined precipitously with longer exposure times at 36 to $44^{\circ} \mathrm{C}$. Colony growth rate was affected by exposure time and colony age, which had significant individual effects at every temperature evaluated, and significant interactions at $36^{\circ} \mathrm{C}$ and 40 to $44^{\circ} \mathrm{C}$ (Supplementary Table S1). At 30 and $32^{\circ} \mathrm{C}$, maximum colony size at 10 days was unaffected by exposures of up to $24 \mathrm{~h}$ (quantile regression; $P>0.1$ ). However, exposure duration was negatively related to colony size and significantly predicted the upper distribution of growth for all temperatures from 34 to $44^{\circ} \mathrm{C}$ (all $\mathrm{P}<$ 0.005). Quantile regressions gave increasingly negative slopes between exposure duration and colony size with higher temperatures; these slopes predicted that colony size would remain at zero
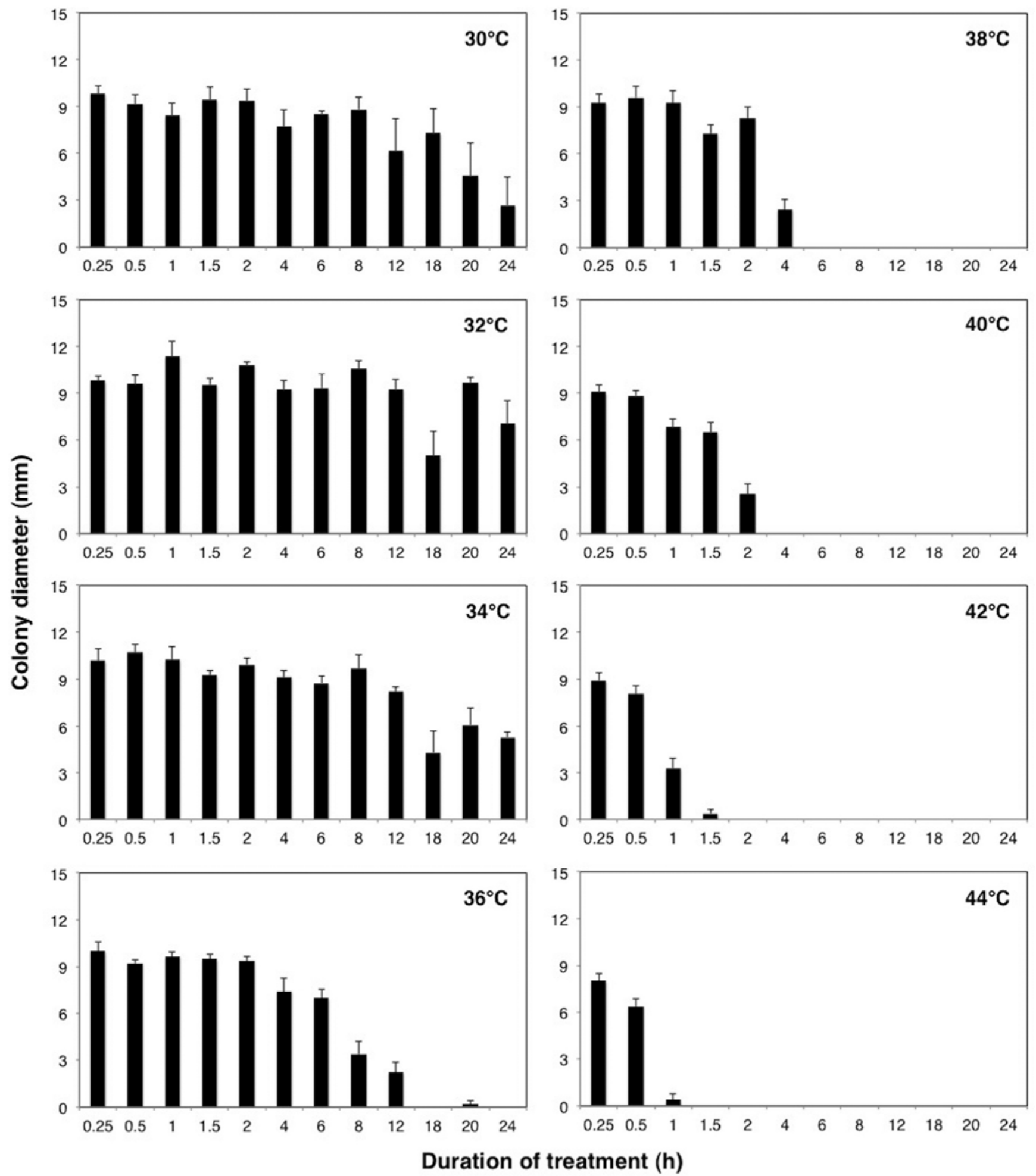

Fig. 1. Effects of temperature and exposure time on Erysiphe necator colony size 10 days following heat treatment to 3-day-old colonies. Error bars indicate $\pm 1 \mathrm{SE}$. 
(no growth) if exposed to $40^{\circ} \mathrm{C}$ for $5.4 \mathrm{~h}, 42^{\circ} \mathrm{C}$ for $1.7 \mathrm{~h}$, or $44^{\circ} \mathrm{C}$ for $1.1 \mathrm{~h}$ (Fig. 2).

Incubation period was monitored to test for sublethal effects of heat treatments. For colonies grown at constant room temperature $\left(22.5^{\circ} \mathrm{C} ; n=125\right)$, incubation periods averaged 5 days. Colonies treated at $30^{\circ} \mathrm{C}$ showed no delay in growth relative to controls (Fig. 3). At 32 and $34^{\circ} \mathrm{C}$, longer exposure times increasingly delayed colony growth in surviving colonies. From 38 to $44^{\circ} \mathrm{C}$, only a few hours of heat exposure led to reduced colony survival and to delays in colony growth for surviving colonies. No colony that was visible 2 days after heat treatment later disappeared during the study.

Spore production. Increasing temperature and exposure duration significantly reduced spore production in E. necator colonies (Table 2; Fig. 4). Colonies grown at 30 to $32^{\circ} \mathrm{C}$ only experienced a gradual decline in spore production with increasing duration of heat exposure but declines were much more dramatic for colonies exposed to 38 to $44^{\circ} \mathrm{C}$. Spore production in colonies held at constant room temperature averaged 131 spores $/ \mathrm{mm}^{2}(n=90)$. The upper limit of spore production was unaffected by the duration of heat exposure at 30 and $32^{\circ} \mathrm{C}$ (quantile regression, $P>0.4$ ). Maximum spore production dropped with increasing heat exposure from 34 to $44^{\circ} \mathrm{C}$ (all $P<0.05$, except at $40^{\circ} \mathrm{C}, P=0.13$; Fig. 2). As with colony growth, at higher temperatures, shorter time exposures were required to shut down spore production: at $40^{\circ} \mathrm{C}, 3.2 \mathrm{~h}$ was sufficient to prevent any spore production, and $1 \mathrm{~h}$ of exposure to $44^{\circ} \mathrm{C}$ was predicted to lead to complete cessation of spore production (Fig. 2).

Spore germination. Spore germination declined with increasing temperature and increasing heat exposure (Fig. 5). Spores from colonies grown at constant room temperature averaged $50.7 \%$ germination $(n=47)$. The maximum percentage of spores successfully germinating was negatively affected by exposure duration at all temperatures examined (all $P<0.02$ ). Negative effects of exposure duration on spore production became increasingly steep from 30 to $44^{\circ} \mathrm{C}$. At $40^{\circ} \mathrm{C}, 4.1 \mathrm{~h}$ of exposure were predicted to lead to total loss of spore viability ( $0 \%$ germination rates); at 42 and $44^{\circ} \mathrm{C}, 2.0$ and $0.5 \mathrm{~h}$, respectively, were predicted to completely inhibit spore germination (Fig. 2).

Field study. The use of the original and revised PMI models reduced the number of fungicide applications relative to applications based on a calendar schedule from six or seven to five applications per trial (Fig. 6). Timing of applications was slightly different within PMI-based managements due to temperature-driven variations of the original model and its revisions; however, each model revision had the same number of applications per season as the original PMI (Fig. 6).

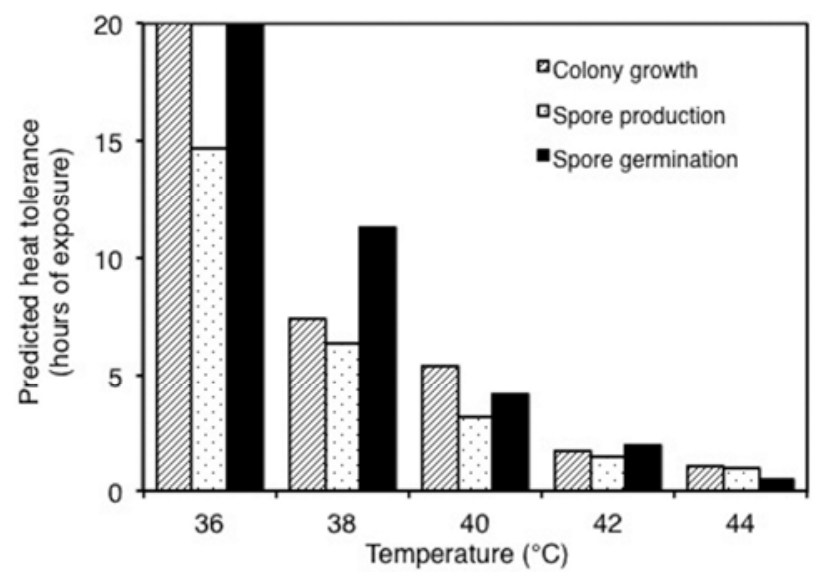

Fig. 2. Predicted maximum duration of heat exposure (h) that could be tolerated by three different life stages of the pathogen. Predictions are $x$-intercepts from quantile regressions that model maximum biological responses to a range of exposures $(0.5$ to $24 \mathrm{~h}$ ) at a range of temperatures $\left(30\right.$ to $44^{\circ} \mathrm{C}$ ). From 30 to $34^{\circ} \mathrm{C}$, all predicted tolerances exceeded $24 \mathrm{~h}$.
Based on the analysis of combined data for the three trials, overall mean powdery mildew incidence on untreated control plants equaled $69.9 \%$ (leaves) and $84.4 \%$ (clusters), whereas disease severity equaled $15.5 \%$ (leaves) and $42.9 \%$ (clusters) (data not shown). Compared with the untreated controls, both calendar- and PMI-based managements at all field locations exhibited much lower powdery mildew incidence and severity (Fig. 7). There were statistically significant differences between management regimes linked to the different high-temperature thresholds; however, especially in the case of disease severity, these differences were not large (Fig. 7). On leaves, the level of disease control (incidence and severity) exhibited by both the original PMI and $38^{\circ} \mathrm{C}$ for $2 \mathrm{~h}$ was statistically equivalent to that of the calendar-based management (Fig. 7). On grape clusters, $36^{\circ} \mathrm{C}$ for $4 \mathrm{~h}$ and $38^{\circ} \mathrm{C}$ for $2 \mathrm{~h}$ model revisions gave significantly lower incidence and severity than the original PMI, which was also statistically equivalent to disease levels observed in the calendar-based management (Fig. 7).

\section{Discussion}

The present study was designed as a systematic time course investigation to better understand the effects of high temperature on the grape powdery mildew pathogen, E. necator, and to assess whether disease managements programs that use the PMI could benefit from a revision of the high-temperature threshold of the model.

In our controlled-environmental experiments, we found that $E$. necator continued to germinate, grow, and sporulate at higher temperatures than previously reported $(10,11,36)$. From 30 to $34^{\circ} \mathrm{C}$, we showed that temperature is not lethal to three of the major stages of the pathogen's asexual life cycle, although long exposure times (up to $24 \mathrm{~h}$ ) at these temperatures reduced growth and reproduction. From 36 to $44^{\circ} \mathrm{C}$, temperature was lethal at progressively shorter intervals. At $44^{\circ} \mathrm{C}$, the predicted lethal duration was $0.5,1$, and $1.1 \mathrm{~h}$ for spore germination, spore production, and colony growth, respectively. Of the three life-cycle stages investigated, the data suggest that spore production may be the event most sensitive to high-temperature exposures (Fig. 2). However, colonies could still produce spores at $44^{\circ} \mathrm{C}$ if exposures were less than $1 \mathrm{~h}$. Colony growth and spore germination were also successful at 42 to $44^{\circ} \mathrm{C}$ if exposure times were of very short duration. Sublethal effects on pathogen growth were manifest as increases in the incubation period (time from inoculation to first appearance of mycelia) and were observed across a wide range of temperatures (32 to $44^{\circ} \mathrm{C}$ ). Although latent period (time from inoculation to conidia formation) was not measured directly, colonies with delayed growth should have also exhibited delays in conidial production. After exposure to $36^{\circ} \mathrm{C}$ for 4 and $6 \mathrm{~h}, 100$ and $94 \%$ of colonies, respectively, grew and sporulated, even though growth was delayed by 1.2 and 1.7 days. These results indicate that high-temperatureinduced delays in incubation and sporulation do not prevent $E$. necator from resuming its life cycle when conditions become favorable. A third major stage of E. necator's asexual life cycleconidial germination-was also reported to recover from sublethal temperatures (10). This suggests that the primary effects of diurnal high-temperature events in the field may be to slow E. necator epidemics by increasing the incubation and latent periods of the fungus.

Although our environmentally controlled study provides a general framework for understanding temperature and exposure period on pathogen growth and survival, our findings cannot be directly extrapolated to field conditions. In our laboratory conditions, we optimized humidity, avoided UV exposure, and applied single isothermal heat treatments, not intended to model diurnal temperature variation. Moreover, colonies that are younger or older than those used in our experiments exposed to the same temperatures may respond differently. Vineyards are likely to create stressful or lethal conditions for E. necator at lower temperatures and shorter exposure times than reported in our environmentally controlled experiments. Moreover, in California vineyards, mildew colonies may be exposed to high temperatures for multiple days in a row as high- 
pressure weather systems move through the region and bring warm temperatures.

Other factors that affect Erysiphe sp. growth and reproduction are difficult to control in the lab. In the field, grape powdery mildew is more successful in shade, in part because shade reduces temperatures by 5 to $10^{\circ} \mathrm{C}$ but also because shade increases relative humidity and decreases solar radiation $(2,18,33,34)$. Laboratory studies have suggested that UVB is the most detrimental compo- nent of solar radiation, may differentially affect spore germination and mycelial growth, and has sublethal effects after multiple exposures (33). E. necator also responds to the physiological status of its host. In addition to its positive correlation with water balance and nutrient status (6), powdery mildew is negatively correlated with grape tissue maturity. Ontogenic resistance in maturing leaves and berries decreases the rate of new infections, and numerous studies pinpoint flowering through fruit set as the most vulnerable
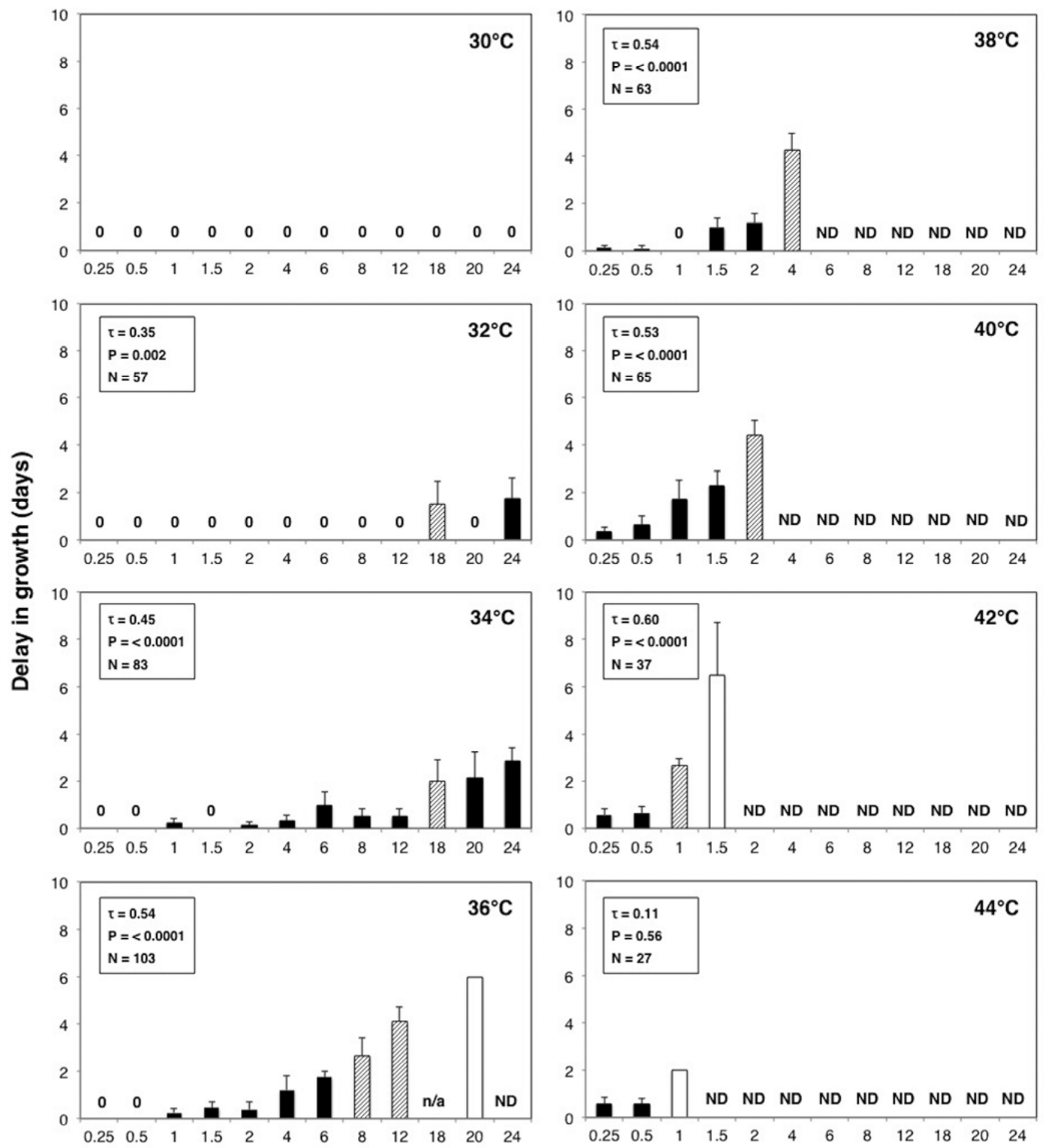

\section{Duration of treatment $(\mathrm{h})$}

Fig. 3. Delay in observable growth of surviving Erysiphe necator colonies following heat treatment at the temperatures and durations shown. Colony survival rates in response to temperature and heat duration varied and are indicated by bar shading (black: $\geq 75 \%$ survival; patterned: $>25 \%$ but $<75 \%$ survival; white: $\leq 25 \%$ survival). ND = no surviving colonies detected; $0=$ no delay in growth relative to room temperature controls; $\mathrm{n} / \mathrm{a}=$ no data collected. Statistical summaries are for Kendall's rank correlation tests. Error bars indicate $\pm 1 \mathrm{SE}$. 
period for E. necator infection $(6,7,13,26)$. This underscores the importance of early season fungicide applications for control of powdery mildew.

Based on the outcomes of the environmentally controlled experiments, in the second phase of our study we used the information on the interactive effects of temperature and duration of exposure to the pathogen's growth and reproduction and tested revisions to the high-temperature threshold of the PMI in field settings. Because most grape-growing areas don't experience long-duration heat spikes that corresponded to lethal conditions in the laboratory, and in order to account for field conditions such as suboptimal humid- ity, increased solar radiation, diurnal temperature swings, wind, and ontogenic resistance, the predicted lethal temperature-duration combinations were adjusted downward. Taking into account the lab-derived data on delay in colony growth after a heat treatment, we focused our field study on three key temperatures which are also routinely seen during the grapevine growing season, and proposed one lower and two higher thresholds of the PMI than the original $\left(35^{\circ} \mathrm{C}\right.$ for $\left.0.25 \mathrm{~h}\right)$, each with a longer duration of exposure $\left(34^{\circ} \mathrm{C}\right.$ for $4 \mathrm{~h}, 36^{\circ} \mathrm{C}$ for $4 \mathrm{~h}$, and $38^{\circ} \mathrm{C}$ for $2 \mathrm{~h}$ ). As per the original PMI model, when these environmental conditions were reached in the field, values of the index were decreased. Although no differ-
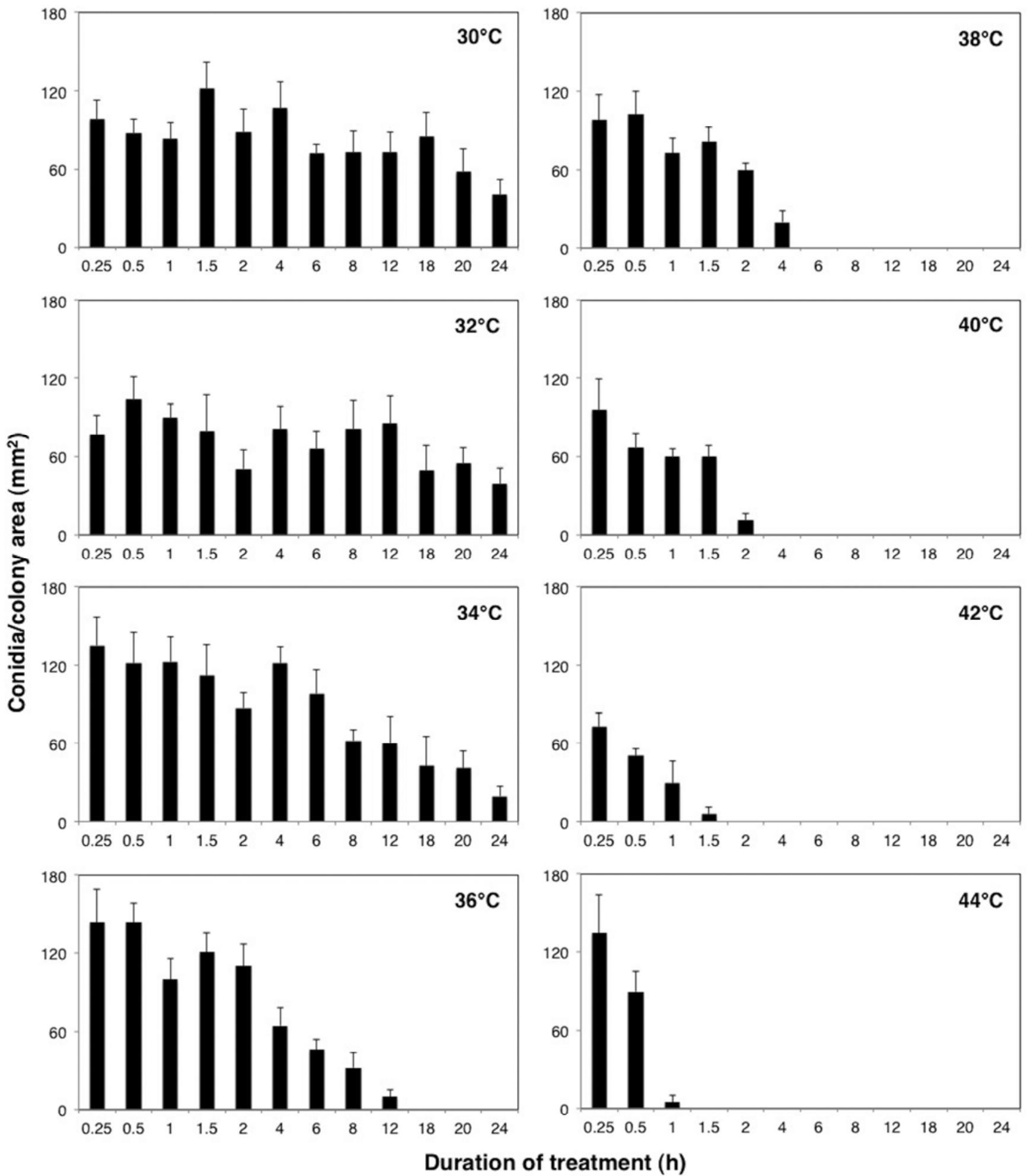

Fig. 4. Effects of temperature and exposure time on Erysiphe necator spore production 10 to 12 days following heat treatment to 3-day-old colonies. Error bars indicate $\pm 1 \mathrm{SE}$. 
ences in the number of fungicide applications resulted from the use of either the original or the revised PMI models, at each site all the model treatments received up to two fewer applications compared with the calendar schedule, which confirms previous studies $(16,20,32)$. Management of powdery mildew using the PMI with the highest temperature threshold $\left(38^{\circ} \mathrm{C}\right.$ for $\left.2 \mathrm{~h}\right)$, consistently resulted in equal (leaves) or better (fruit) disease control compared with the original PMI, and also provided disease control equal to the calendar schedule but with five fewer fungicide applications over the two seasons tested. Although our data did not show evidence of reduced fungicide use between the original PMI and $38^{\circ} \mathrm{C}$ for $2 \mathrm{~h}$, the timing of fungicide application differed due to temperature-driven variations in computation of the original and revised models and could lead to a reduced number of fungicide applications during some growing seasons. Data on pathogen mortality occurring at times indicated by the model thresholds was not collected during this study, and the different timing of sprays was considered the principal cause of the observed effects on disease suppression. Additional data on pathogen mortality in the field would strengthen our understanding of powdery mildew responses to temperature stress.

In conclusion, our study underlines the interactive effects of temperature and duration of exposure on E. necator's ability to
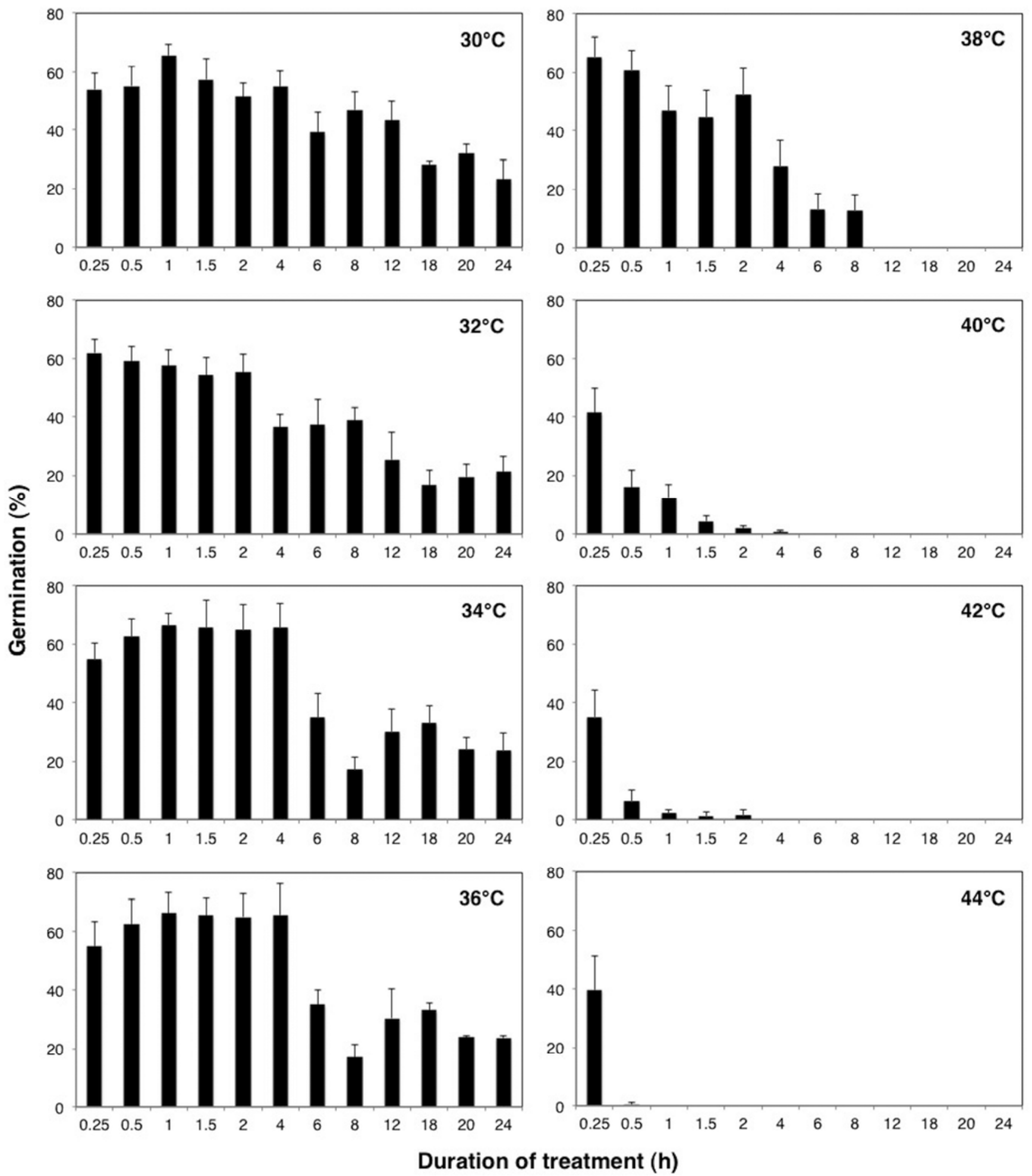

Fig. 5. Effects of temperature and exposure time on Erysiphe necator spore germination in 15-day old colonies. Error bars indicate \pm 1 SE. 
Sacramento Co. (2011)

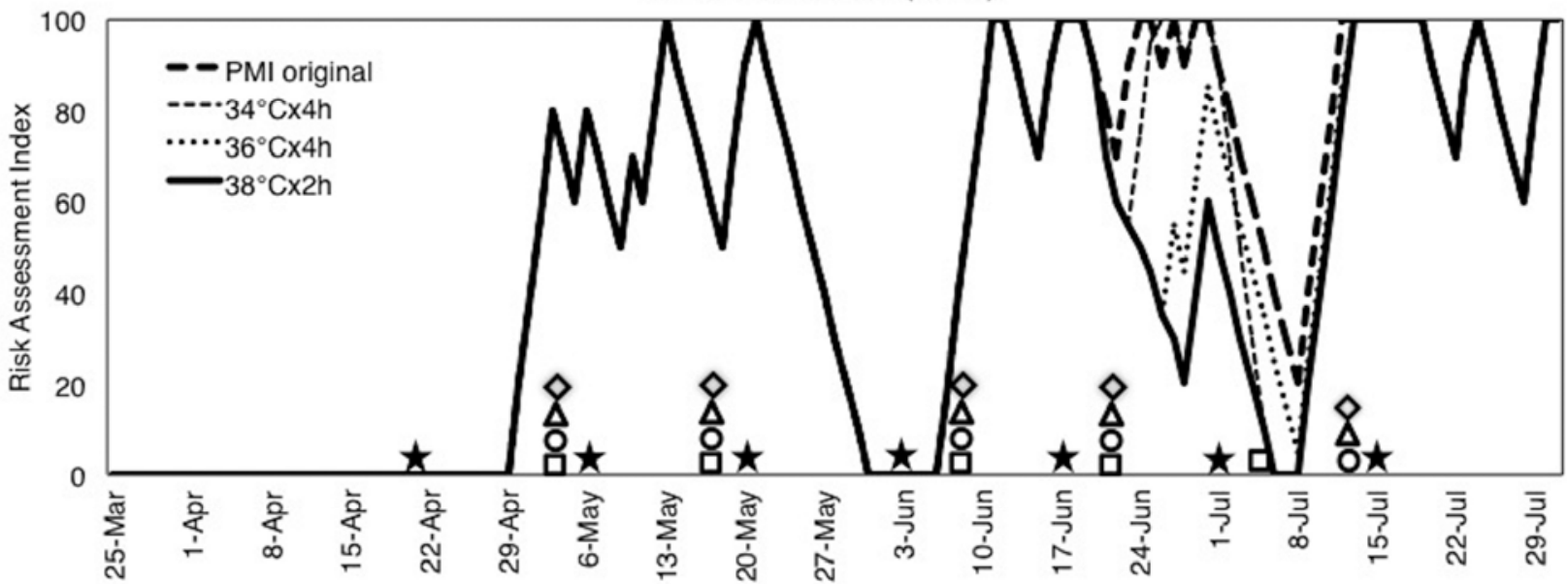

Solano Co. (2011)

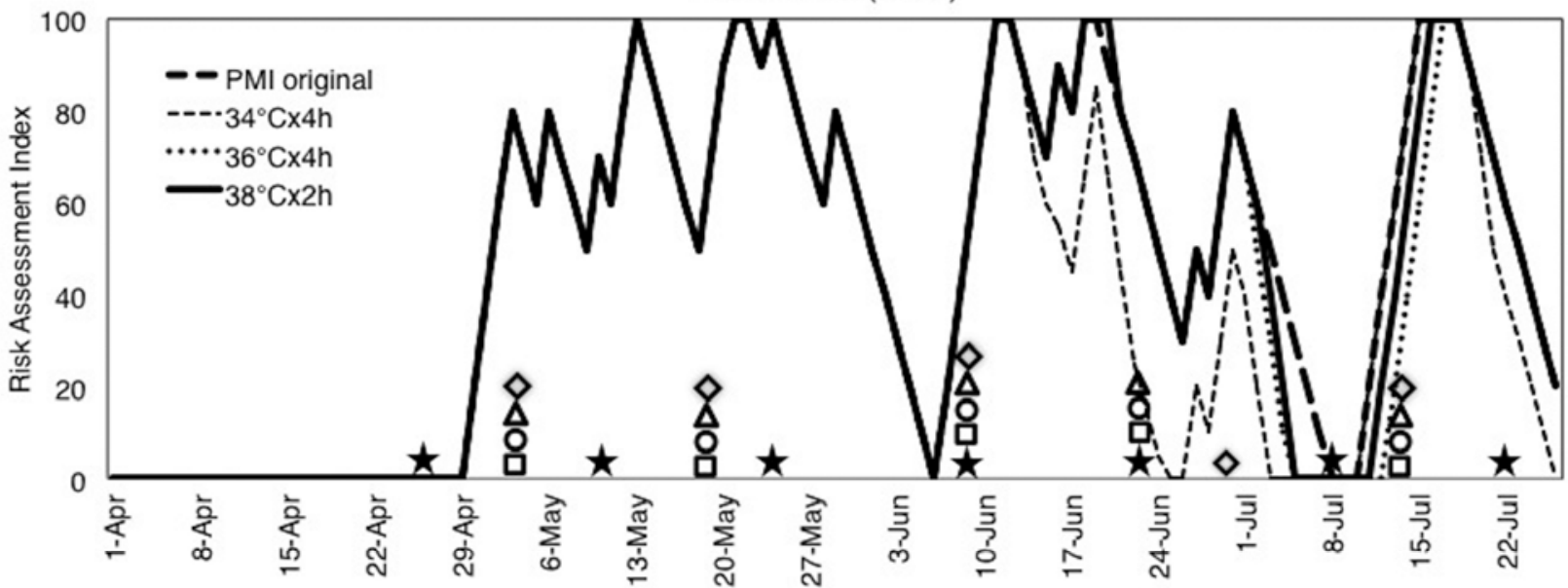

Fresno Co. (2012)

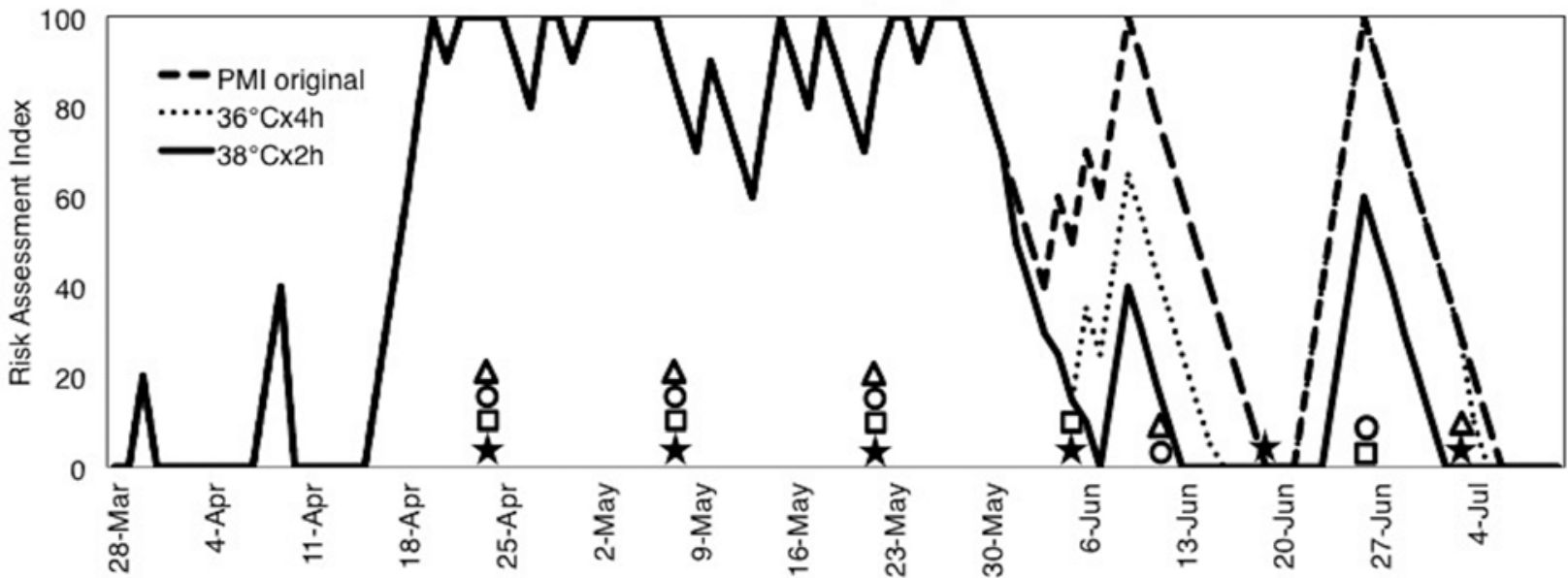

Fig. 6. Temporal evolution of the original Powdery Mildew Risk Index (PMI) and risk index according to the model revisions tested in this study. Fungicide applications were made based on a calendar schedule (every 14 days) or according to model predictions.

grow and reproduce. Our controlled-environment data provided us with useful information on how to refine the high-temperature threshold of the UC Davis PMI, which is a tool extensively used in California to predict temporal variation in mildew epidemics. Our field data complemented our controlled-environment data by taking into account factors that may be difficult to replicate in the lab (i.e., UV radiation, ontogenic resistance, and diurnal temperature fluctuations). After 2 years of testing revisions to the original PMI in the vineyard, we can conclude that the highest temperature threshold evaluated $\left(38^{\circ} \mathrm{C}\right.$ for $\left.2 \mathrm{~h}\right)$ has the most potential to further reduce fungicide applications while providing adequate disease control. 

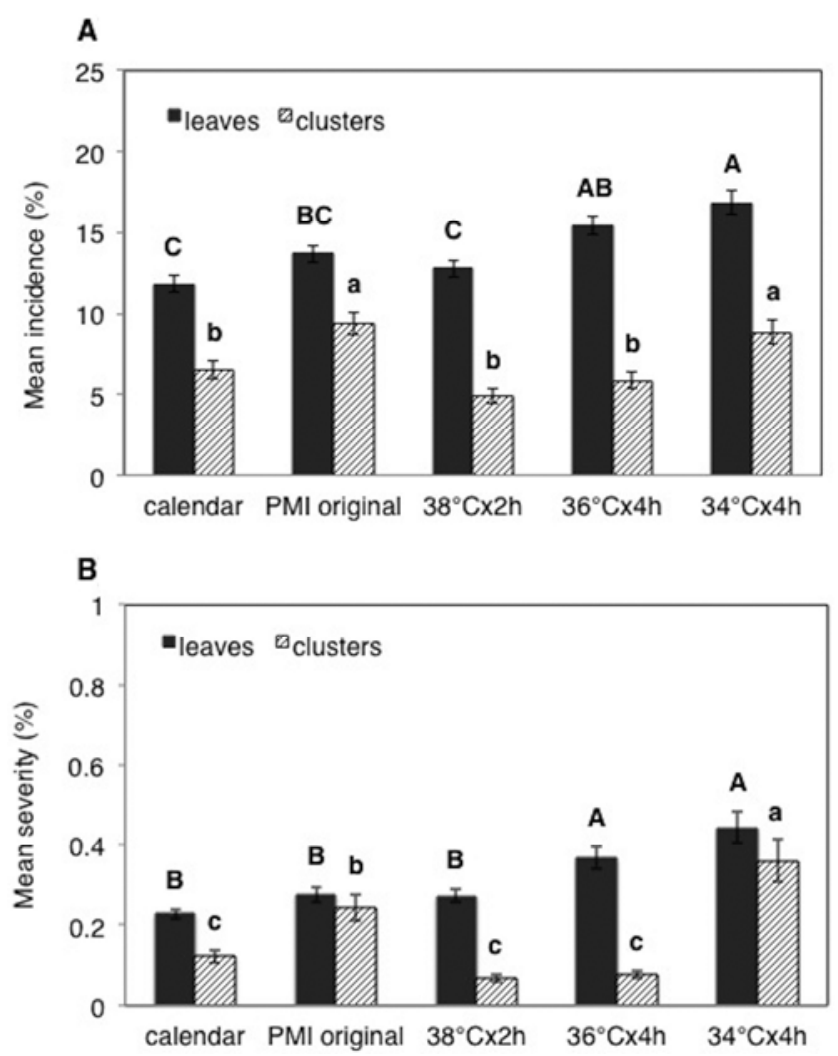

Fig. 7. Effect of fungicide applications timed according to the original Powdery Mildew Risk Index (PMI), revised risk index models, and a 14-day calendar schedule on grapevine powdery mildew $\mathbf{A}$, incidence and $\mathbf{B}$, severity on leaves and fruit (mean $\pm 1 \mathrm{SE}$ ). Mean disease incidence on untreated control plants equaled $69.9 \%$ (leaves) and $84.4 \%$ (clusters), while disease severity equaled $15.5 \%$ (leaves) and $42.9 \%$ (clusters). Means comparison performed via Tukey honestly significant difference using least squared means. Levels with different letters are significantly different $(\alpha=0.05)$.

\section{Acknowledgments}

This work was supported by the American Vineyard Foundation, the United States Department of Agriculture Viticulture Consortium-West, the CDFA Specialty Crop Block Grant SCB09057, and the UC Davis Department of Plant Pathology. Part of the research described in this article represents a portion of the thesis submitted by P. Backup to the Office of Graduate Studies of the University of California, Davis to partially fulfill requirements for the M.S. degree in Plant Pathology. We thank M. A. Link, who performed part of the statistical analyses for this project; and I. Bay, J. Eynard, T. Nguyen, R. Doody, R. Choudhury, A. Sutherland, L. Duffau, and L. Schiller, who assisted with fungicide applications and disease rating in the field.

\section{Literature Cited}

1. Aust, H. J., and Hoyningen-Huene, J. V. 1986. Microclimate in relation to epidemics of powdery mildew. Annu. Rev. Phytopathol. 24:491-510.

2. Austin, C. N., Grove, G. G., Meyers, J. M., and Wilcox, W. F. 2011. Powdery mildew severity as a function of canopy density: associated impacts on sunlight penetration and spray coverage. Am. J. Enol. Vitic. 62:23-31.

3. Cade, B. S., and Noon B. R. 2003. A gentle introduction to quantile regression for ecologists. Front. Ecol. Environ. 1:412-420.

4. Caffi, T., Rossi, V., Legler, S. E., and Bugiani, R. 2011. A mechanistic model simulating ascosporic infections by Erysiphe necator, the powdery mildew fungus of grapevine. Plant Pathol. 60:522-531.

5. Calonnec, A., Cartolaro, P., and Chadoeuf, J. 2009. Highlighting features of spatiotemporal spread of powdery mildew epidemics in the vineyard using statistical modeling on field experimental data. Phytopathology 99:411-422.

6. Calonnec, A., Cartolaro, P., Naulin, J.-M., Bailey, D., and Langlais, M. 2008. A host-pathogen simulation model: powdery mildew of grapevine. Plant Pathol. 57:493-508.

7. Campbell, P., Bendek, C., and Latorre, B. A. 2007. Risk of powdery mildew (Erysiphe necator) outbreaks on grapevines in relation to cluster development. Cienc. Invest. Agrar. 34:1-6.

8. Carisse, O., Bacon, R., Lefebvre, A., and Lessard, K. 2009. A degree-day model to initiate fungicide spray programs for management of grape powdery mildew [Erysiphe necator]. Can. J. Plant Pathol. 31:186-194.
9. Chellemi, D. O., and Marois, J. J. 1991. Development of a demographic growth model for Uncinula necator by using a microcomputer spreadsheet program. Phytopathology 81:250-254.

10. Delp, C. J. 1953. Some environmental factors which influence the development of the grape powdery mildew fungus, Uncinula necator (Schw.) Burr. Ph.D. dissertation, University of California, Davis.

11. Delp, C. J. 1954. Effect of temperature and humidity on the grape powdery mildew fungus. Phytopathology 44:615-626.

12. Epstein, L., and Bassein, S. 2003. Patterns of pesticide use in California and the implications for strategies for reduction of pesticides. Annu. Rev. Phytopathol. 41:351-375.

13. Ficke, A., Gadoury, D. M., Seem, R. C., and Dry, I. B. 2003. Effects of ontogenic resistance upon establishment and growth of Uncinula necator on grape berries. Phytopathology 93:556-563.

14. Gadoury, D. M., Seem, R. C., Ficke, A., and Wilcox, W. F. 2001. The epidemiology of powdery mildew on Concord grapes. Phytopathology 91:948955.

15. Glawe, D. A. 2008. The powdery mildews: a review of the world's most familiar (yet poorly known) plant pathogens. Annu. Rev. Phytopathol. 46:27-51.

16. Gubler, W. D., Rademacher, M. R., Vasquez, S. J., and Thomas, C. S. 1999. Control of powdery mildew using the UC Davis powdery mildew risk index. APSnet Feature. Online. The American Phytopathological Society, St. Paul, MN. doi: 10.1094/APSnetFeature-1999-0199

17. Hoagland, D. R., and Snyder, W. C. 1933 . Nutrition of the strawberry plant under controlled conditions. Am. Soc. Hortic. Sci. Proc. 30:288-294.

18. Jarvis, W. R., Gubler, W. D., and Grove, G. G. 2002. Epidemiology of powdery mildews in agricultural pathosystems. Pages 169-199 in: The Powdery Mildews: A Comprehensive Treatise. R. R. Belanger, W. R. Bushnell, A. J. Dik, and T. L. W. Carver, eds. American Phytopathological Society, St. Paul, MN.

19. Klempka, K. C., Meredith, C. P., and Sall, M. A. 1984. Dual culture of grape powdery mildew (Uncinula necator Burr.) on its host (Vitis vinifera L.). Am. J. Enol. Vitic. 35:170-174.

20. Lybbert, T. J., and Gubler, W. D. 2008. California wine grape growers' use of powdery mildew forecasts. Agric. Resour. Econ. Update 11:11-14.

21. Miller, T. C., and Gubler, W. D. 2003. Effects of temperature and water vapor pressure on conidial germination and lesion expansion of Sphaerotheca macularis f. sp. fragariae. Plant Dis. 87:484-492.

22. Morrison, R. M. 1960. Studies of clonal isolates of Erysiphe cichoracearum on leaf disk culture. Mycologia 52:388-393.

23. Moyer, M. M., Gadoury, D. M., Cadle-Davidson, L., Dry, I. B., Magarey, P. A., Wilcox, W. F., and Seem, R. C. 2010. Effects of acute low-temperature events on development of Erysiphe necator and susceptibility of Vitis vinifera. Phytopathology 100:1240-1249.

24. Nicot, P. C., Bardin, M., and Dik, A. J. 2002. Basic methods for epidemiological studies of powdery mildews: culture and preservation of isolates, production and delivery of inoculum, and disease assessment. Pages 83-99 in: The Powdery Mildews. A Comprehensive Treatise. R. R. Belanger, W. R. Bushnell, A. J. Dik, and T. L. W. Carver, eds. American Phytopathological Society, St. Paul, MN.

25. Pearson, R. C., and Gadoury, D. M. 1992. Powdery mildew of grape. Pages 129-146 in: Plant Diseases of International Importance. Vol III. Diseases of Fruit Crops. J. Kumar, H. S. Chaube, U. S. Singh, and A. N. Mukhopadhyay, eds. Prentice Hall, Englewood Cliffs, NJ.

26. Peros, J. P., Nguyen, T. H., Troulet, C., Michel-Romiti, C., and Notteghem, J. L. 2006. Assessment of powdery mildew resistance of grape and Erysiphe necator pathogenicity using a laboratory assay. Vitis 45:29-36.

27. Reeser, P., Hagedorn, D. J., and Rouse, D. I. 1983. Quantitative inoculations with Erysiphe pisi to assess variation of infection efficiency on peas. Phytopathology 73:1238-1240.

28. Sall, M. A. 1980. Epidemiology of grape powdery mildew: a model. Phytopathology 70:338-342.

29. Sall, M. A., Wrysinki, J., and Schick, F. J. 1983. Temperature-based sulfur applications to control grape powdery mildew. Calif. Agric. 37:4-5.

30. Schnathorst, W. C. 1960. Effects of temperature and moisture stress on the lettuce powdery mildew fungus. Phytopathology 50:304-308.

31. Thomas, C. S., Skinner, P. W., Fox, A. D., Greer, C. A., and Gubler, W. D. 2002. Utilization of GIS/GPS-based information technology in commercial crop decision making in California, Washington, Oregon, Idaho, and Arizona. J. Nematol. 34:200-206.

32. Weber, E., Gubler, D., and Derr, A. 1996. Powdery mildew controlled with fewer fungicide applications. Pract. Wine. Vineyard 16:13-16.

33. Willocquet, L., Colombet, D., Rougier, M., Fargues, J., and Clerjeau, M. 1996. Effects of radiation, especially ultraviolet B, on conidial germination and mycelial growth of grape powdery mildew. Eur. J. Plant Pathol. 102:441-449.

34. Yarwood, C. E. 1957. Powdery mildews. Bot. Rev. 33:235-301.

35. Yarwood, C. E., Sidky, S., Cohen, M., and Santilli, V. 1954. Temperature relations of powdery mildews. Hilgardia 22:603-622.

36. Ypema, H. L., and Gubler, W. D. 1997. Long-term effect of temperature and triadimefon on proliferation of Uncinula necator: implications for fungicide resistance and disease risk assessment. Plant Dis. 81:1187-1192. 